\title{
THE INTRAVENOUS GALACTOSE TOLERANCE TEST IN INFANCY
}

\author{
BY \\ G. M. THEODORE, J. D. FORD, and J. C. HAWORTH* \\ From the Winnipeg Children's and General Hospitals and the Department of Paediatrics, University of Manitoba, Canada
}

(RECEIVED FOR PUBLICATION APRIL 13, 1964)

Galactose metabolism in infancy has attracted much interest because of the nutritional importance of this sugar during the first few months of life. Lactose, each molecule of which is normally hydrolysed in the gut to one molecule of glucose and one of galactose, forms about $40^{\circ}{ }_{o}^{\prime}$ of the caloric intake of the fully breast-fed infant. Galactose, after absorption, is transported to the liver where its metabolism into glucose compounds principally occurs. Galactose tolerance, therefore, has been used as a measure of liver function.

Hartmann and his co-workers (Hartmann, Grunwaldt, and James, 1953; Hartmann, McCoy, Swarm, and Nakasato, 1954) found that normal premature and full-term infants could metabolize galactose normally at birth. These authors also reported that in infants after milk feedings as much as $40 \%$ of the blood sugar might be galactose and that after an oral dose of galactose the rise in blood sugar might be entirely due to galactose, the blood glucose falling and then rising later as the galactose fell. Dormandy, Leak, and Grant (1959) reported rather similar findings in newborn infants fed breast milk.

We have previously reported findings different from the above (Haworth and Ford, 1960, 1963). In infants fed lactose or galactose by mouth, we found that there was invariably a rise in the blood glucose level. Newborn infants less than 8 days of age showed lower fasting blood glucose levels and a greater rise in glucose following galactose ingestion than older children and adults. In addition, galactose was much less frequently demonstrated in the blood of these younger infants. These findings were thought to suggest that infants less than 1 week of age had a greater ability to convert galactose to glucose than older infants and children, but variation in the rate of absorption from the sugar from the intestine might also have explained the differences.

- Present address: The Winnipeg Clinic. Winnipeg 1. Manitoba,
Galactose metabolism may best be studied by administering the sugar intravenously, thus eliminating the absorptive factor. Vink and Kroes (1959) performed intravenous galactose tolerance tests on subjects of different ages and found a greater disappearance rate from the blood in youth. Mulligan and Schwartz (1962) administered galactose intravenously to infants from 3 to 5 hours of age and reported diminished elimination of the sugar from the blood as compared with that of older individuals. Cornblath, Wybregt, and Baens (1963) found that galactose was cleared more slowly from the blood in the premature infant than it was in the adult.

It seemed desirable to obtain more information on the metabolism of galactose in the normal infant during the first month of life, and this is a report of our findings of the intravenous galactose tolerance test in infants aged from 1 to 31 days.

\section{Subjects and Methods}

Single intravenous galactose tolerance tests were performed on 30 full-term apparently normal infants, who were divided by age into three groups of 10 infants in each group: Group 1 were 1-2 days of age; Group 2 were 3-7 days of age; and Group 3 were 21-31 days of age. Of the 30 infants 15 were male and 15 female, and sex distribution was approximately equal within the groups.

Four additional infants were each tested two or three times to determine individual variation with age.

Tests were performed after a four-hour fast. Galactose $\left(0.5 \mathrm{~g} . / \mathrm{kg}\right.$. body weight) was administered as a $25^{\circ} \mathrm{o}$ solution through a scalp vein during a two-minute interval. Capillary blood samples obtained by heel prick were taken fasting and at $15,30,45,60,90$, and 120 minutes after the start of the injection. Each blood sample was obtained within $2 \frac{1}{2}$ minutes. The blood was kept in heparinized tubes in an ice-bath during the tests and after separation the plasma was frozen until analysed.

Total sugar was estimated by the method of King and Wootton (1956). The standard deviation of 21 duplicate samples by this method was found by us to be $\doteq 2.04$ $\mathrm{mg}$./100 $\mathrm{ml}$. Glucose was estimated by the glucose-oxidase 
method of Huggett and Nixon (1957) as modified by Haworth and Ford (1960), the standard deviation of 21 duplicate samples being $=2.07 \mathrm{mg} . / 100 \mathrm{ml}$.

The copper reduction method was found to measure $73^{\circ}$ o of galactose, setting glucose as $100^{\circ} \%$. Therefore, in calculating the galactose concentration, the value for glucose obtained by glucose oxidase was subtracted from that obtained by copper reduction and the remainder divided by 0.73 to give milligrams of galactose $/ 100 \mathrm{ml}$. plasma.

The rate of decline of plasma galactose was calculated on the basis of the amount of galactose remaining in the blood, rather than on the change in total sugar.

The rate of decline of galactose was treated as an exponential function of time (West and Wood, 1959; Colcher, Patek, and Kendall, 1946) and was calculated during the interval 15 to 60 minutes, when it was presumed to be constant. The theoretical initial plasma concentration of galactose, the physiological half-life, and the rate of disappearance were calculated.

\section{Results}

The results are shown in Table 1. It is apparent that a great deal of variation in half-life, disappearance rate, and initial concentration existed within each group of infants. The mean value of half-life for Group 1 was $19 \cdot 7$ minutes, for Group 2, $19 \cdot 5$ minutes, and for Group 3, 16.6 minutes. There were no statistically significant differences between the groups for disappearance rate, half-life, or initial concentration of galactose when the figures were subjected to an analysis of variance $(p>0.05)$.

The plasma glucose levels for the three groups were also analysed. The mean fasting plasma glucose levels for Groups 1 and 2 were $59.0 \mathrm{mg}$./ $100 \mathrm{ml}$. and $60.4 \mathrm{mg} . / 100 \mathrm{ml}$., respectively. The mean fasting plasma glucose level of Group 3 was $78.9 \mathrm{mg}$. $/ 100 \mathrm{ml}$. which differed significantly from Groups 1 and $2(p<0.001)$. The fasting plasma glucose levels were plotted against the rise of glucose over the first 15 minutes of the tests. The slope of the relation was calculated by least squares curve fit and found to be positive. An analysis of the slope by the ' $t$ ' test showed it to be significantly different from zero $(p<0.05)$. Therefore, the higher the fasting plasma glucose level, the greater the rise in glucose from the fasting level as measured at 15 minutes.

The results of four infants on whom the intravenous galactose test was performed repeatedly, are shown in Table 2. The initial galactose concentration, half-life, and disappearance rate were calculated as above. Again it is seen that there was much variation both between infants and in each infant at different ages.

TABLE 1

RESULTS OF INTRAVENOUS GALACTOSE TOLERANCE TEST IN 30 INFANTS

\begin{tabular}{|c|c|c|c|c|c|c|c|c|}
\hline Group & $\begin{array}{c}\text { Age Range } \\
\text { (days) }\end{array}$ & $\begin{array}{l}\text { No. of } \\
\text { Subjects }\end{array}$ & $\begin{array}{l}\text { Weight Mean } \\
\text { and Range (kg.) }\end{array}$ & $\begin{array}{c}\text { Fasting } \\
\text { Glucose } \\
\text { Mean and } \\
\text { Range } \\
\text { (mg./100ml.) }\end{array}$ & $\begin{array}{c}\text { Initial } \\
\text { Galactose } \\
\text { Conc. Mean } \\
\text { and Range } \\
\text { (mg. } 100 \text { ml.) }\end{array}$ & $\begin{array}{l}15 \mathrm{~min} . \\
\text { Glucose Mean } \\
\text { and Range } \\
\text { (mg. } / 100 \mathrm{ml} .)\end{array}$ & $\begin{array}{c}\text { Galactose } \\
\text { Half-life Mean } \\
\text { and Range (min.) }\end{array}$ & $\begin{array}{c}\text { Galactose } \\
\text { Disappearance Rate } \\
\text { Mean (= S.E.) and } \\
\text { Range }(\% \text { min.) }\end{array}$ \\
\hline 1 & $1-2$ & 10 & $\begin{array}{c}3 \cdot 29 \\
2 \cdot 84-3 \cdot 97\end{array}$ & $\begin{array}{c}59 \cdot 0 \\
39-81\end{array}$ & $\begin{array}{c}99 \cdot 5 \\
65-123\end{array}$ & $\begin{array}{c}87 \cdot 4 \\
70-108\end{array}$ & $\begin{array}{c}19 \cdot 7 \\
15 \cdot 8-23 \cdot 8\end{array}$ & $\begin{array}{c}3 \cdot 5(=0 \cdot 13) \\
3 \cdot 0-4 \cdot 1\end{array}$ \\
\hline 2 & $3-7$ & 10 & $\frac{3 \cdot 28}{2 \cdot 50-4 \cdot 03}$ & $\begin{array}{c}60 \cdot 4 \\
44-73\end{array}$ & $\begin{array}{l}114 \cdot 9 \\
60-255\end{array}$ & $\begin{array}{c}96 \cdot 9 \\
61-125\end{array}$ & $\begin{array}{l}19 \cdot 5 \\
9 \cdot 9-30 \cdot 1\end{array}$ & $\begin{array}{c}3 \cdot 9(=0 \cdot 38) \\
2 \cdot 3-6 \cdot 9\end{array}$ \\
\hline 3 & $21-31$ & 10 & $\begin{array}{c}3 \cdot 87 \\
3 \cdot 06-4 \cdot 94\end{array}$ & $\begin{array}{c}78 \cdot 9 \\
74-96\end{array}$ & $\begin{array}{c}136 \cdot 2 \\
65-232\end{array}$ & $\begin{array}{c}118 \cdot 4 \\
104-135\end{array}$ & $\begin{array}{c}16 \cdot 6 \\
7 \cdot 8-26 \cdot 8\end{array}$ & $\begin{array}{c}5 \cdot 8(=0 \cdot 68) \\
2 \cdot 5-8 \cdot 7\end{array}$ \\
\hline
\end{tabular}

TABLE 2

RESULTS OF SERIAL INTRAVENOUS GALACTOSE TOLERANCE TESTS IN FOUR INFANTS

\begin{tabular}{|c|c|c|c|c|c|c|}
\hline Subject & & Age (days) & Weight (kg.) & $\begin{array}{l}\text { Initial Galactose } \\
\text { Concentration } \\
\text { (mg./100 ml.) }\end{array}$ & Half-life (min.) & $\begin{array}{c}\text { Galactose } \\
\text { Disappearance Rate } \\
(\% \text { min.) }\end{array}$ \\
\hline $\mathbf{M}$ & 1 & $\begin{array}{r}1 \\
9 \\
15\end{array}$ & $\begin{array}{l}2 \cdot 76 \\
2 \cdot 72 \\
2 \cdot 86\end{array}$ & $\begin{array}{r}192 \\
88 \\
73\end{array}$ & $\begin{array}{r}9 \cdot 5 \\
8 \cdot 3 \\
15 \cdot 1\end{array}$ & $\begin{array}{l}7 \cdot 37 \\
8 \cdot 29 \\
4 \cdot 61\end{array}$ \\
\hline $\mathbf{P}$ & \{ & $\begin{array}{l}3 \\
9\end{array}$ & $\begin{array}{l}2 \cdot 99 \\
2 \cdot 96\end{array}$ & $\begin{array}{l}24 \\
64\end{array}$ & $\begin{array}{l}33 \cdot 5 \\
19 \cdot 7\end{array}$ & $\begin{array}{l}2 \cdot 07 \\
3 \cdot 45\end{array}$ \\
\hline $\mathbf{H}$ & 1 & $\begin{array}{r}2 \\
9 \\
20\end{array}$ & $\begin{array}{l}3 \cdot 01 \\
3 \cdot 03 \\
3 \cdot 18\end{array}$ & $\begin{array}{l}82 \\
68 \\
67\end{array}$ & $\begin{array}{l}32 \cdot 1 \\
22 \cdot 5 \\
17 \cdot 1\end{array}$ & $\begin{array}{l}2 \cdot 07 \\
2 \cdot 38 \\
4 \cdot 16\end{array}$ \\
\hline $\mathbf{N}$ & $!$ & $\begin{array}{r}5 \\
17 \\
28\end{array}$ & $\begin{array}{l}3 \cdot 20 \\
3 \cdot 23 \\
3 \cdot 37\end{array}$ & $\begin{array}{l}73 \\
69 \\
86\end{array}$ & $\begin{array}{r}13 \cdot 4 \\
9 \cdot 9 \\
13 \cdot 7\end{array}$ & $\begin{array}{l}5 \cdot 30 \\
6 \cdot 91 \\
5 \cdot 07\end{array}$ \\
\hline
\end{tabular}




\section{Discussion}

The results of intravenous galactose administration in the three groups showed no statistically significant difference in the mean values of initial concentration, half-life, or removal rate of plasma galactose. Tests repeated on the same individual also showed no evidence of a trend in these measurements with age, though great variation was observed from subject to subject and in each subject at different times. It is, therefore, concluded that infants between 1 and 31 days of age show no mean difference in their ability to remove intravenously administered galactose. This is in agreement with the results in premature infants reported by Cornblath et al. (1963) who showed no change in the rate of removal of galactose between 2 hours and 18 days of age.

The rate of galactose elimination in normal adults has been reported to be between $4 \cdot 2$ and $9 \cdot 5^{\circ}$ per minute (Colcher et al., 1946). The present results are similar, though somewhat lower. Vink and Kroes (1959) reported the elimination rate to be higher in young children, though they did not apparently study infants.

Mulligan and Schwartz (1962) reported a slower rate of elimination of intravenously administered galactose in infants under 8 hours in terms of the half-life.

In every instance we found that the intravenous administration of galactose resulted in a rise of the plasma glucose, and a fall was never observed. Haworth and Ford (1960, 1963), Mulligan and Schwartz (1962), and Cornblath et al. (1963) also reported a consistent rise in blood glucose after galactose administration, whereas Hartmann et al. (1953, 1954) and Dormandy et al. (1959) found that the blood glucose level often declined after galactose.

\section{Summary}

Intravenous galactose tolerance tests were performed on 30 infants aged 1 to 31 days. Four additional infants were each tested two or three times.
The average rate of elimination of galactose from the plasma of the infants did not vary within the first month of life, though large individual variations occurred.

The fasting plasma glucose level was significantly higher in those infants aged 21 to 31 days as compared with those aged 1 to 7 days. There was also a statistically significant correlation between the fasting glucose level and the rise in glucose 15 minutes after the intravenous injection of galactose.

Dr. R. J. Cadoret gave invaluable assistance in the analysis of the results.

This work was supported by a grant from the Medical Research Council of Canada.

\section{REFERENCES}

Colcher. H.. Patek. A. J., Jr.. and Kendall. F. E. (1946). Galactose disappearance from the blood stream. Cakculation of a galactose removal constant and its application as a test for liver function. J. clin. Invest., 25, 768.

Comblath, M., Wybregt. S. H., and Baens, G. S. (1963). Studies of carbohydrate metabolism in the newborn infant. VII. Tests of carbohydrate tolerance in premature infants. Pediatrics, 32, 1007.

Dormandy, T. L.. Leak, D.. and Grant. M. (1959). Hypoglycamia induced by galactose. Lancet, 2, 269.

Hartmann, A. F., Grunwaldt, E., and James. D. H., Jr. (1953). Blood galactose in infants and children. J. Pediat., 43, 1.

McCoy, E. E., Swarm, P. A., and Nakasato, D. I. (1954). Further observations on the metabolism of galactose in infants and children. ibid. .44, 499.

Haworth. J. C., and Ford, J. D. (1960). Blood-sugar in infants after lactose feeds. Lancet, 2, 794.

- _ (1963). Variation of the oral galactose tolerance test with age. J. Pediat., 63, 276.

Huggett, A. St. G., and Nixon, D. A. (1957). Use of glucose oxidase. peroxidase, and o-dianisidine in determination of blood and urinary glucose. Lancet. 2. 368.

King. E. J., and Wootton, D. P. (1956). Micro-analysis in Medical Biochemistry, 3rd ed. Churchill, London.

Mulligan, P. B., and Schwartz, R. (1962). Hepatic carbohydrate metabolism in the genesis of neonatal hypoglycemia. Effects of administration of epinephrine, glucagon, and galactose. Pediatrics, 30, 125.

Vink, C. L. J., and Kroes. A. A. (1959). Liver function and age. Clin. chim. Acta, 4, 674.

West. K. M.. and Wood, D. A. (1959). The intravenous glucose tolerance test. Amer. J. med. Sci., 238. 25. 